\title{
The Implementation of LAVIR Networking Model at Vocational School (Efforts To Foster Students' Learning Responses Through Visual Literacy)
}

\author{
Sapto Haryoko, Hendra Jaya \\ Electronics Engineering Education Department, Engineering Faculty \\ Universitas Negeri Makassar \\ Makassar, Indonesia \\ sapto.haryoko@unm.ac.id
}

\begin{abstract}
This study aims to determine the process of application of lavir networking model in learning. This research is a type of quantitative research with quasi experiment method. The data were analyzed descriptively and hypothesis test (anova) then further tested using scheffe test and tukey test. The results showed that there was average difference between experimental class with Pretest and control class with Pretest which was $\mathbf{7 . 5 2}$ for experiment non pretest class was 5.63, for non pre test control class was 12.000 with error standard 1.60, and significance 0.000 (less from 0.05 ) showing that there was a significant difference between the mean normal values of the experiment with control class and the control-pretest class, the non-pretest experimental class and the non-pretest control class. The conclusion of this research is the process of applying lavir networking model in learning emphasized on virtual practicum process by using computer media aiming for learners to know the maximum learning skill.
\end{abstract}

Keywords- Lavir Netwoking, Computer Network
Engineering

\section{INTRODUCTION}

Education has a very important role in human life. Along with the progress of science and technology, it is necessary that professional teachers can perform their duties as educators, teachers, coaches and trainers of the nation's children in the future that can provide an active, creative, innovative learning direction and high interest in learners. Law no. 20 of 2003 on the National Education System stated that "learning is the process of interaction of learners with teachers and learning resources in a learning environment". In addition to the development of education and science, the development of science and computer technology is also growing rapidly, thus, it is needed to raise the demand to replace the old process by utilizing computer functions [1].

Computers as data processing tools can improve efficiency and performance [2,3]. By the time the computer has become one of the main needs, the exchange of data into things are often done, so that the network is needed as a traffic transfer data. The use of networks in an activity will affect the efficiency of time and costs incurred because the collection of data information can be done quickly and easily. The implementation of this network is done by connecting one computer with another computer by using some network to form a local network called Local Area Network (LAN).
One of the facilities of computer network is we can do various information or sharing data [4], various resources and many more advantages can be taken from existence of computer network, but there are also some people who do not know it. Sometimes, some people have been accustomed to using computer network, but some of them do not understand the benefits of the computer network, so it can cause negative things. This can be felt by the increasing number of systems found based computer network. In addition to the performance of a system can be increased, information technology can offer an ease in managing and running the system. In this fast-paced and instant era, the use of computer networks is very useful and effective. New devices are increasingly emerging to support the development of information technology.

However, with the rapid development of technology many educational institutions are not able to keep up with current technological advances. While the quality of education is determined on the learning process that takes place in classrooms, the development of information and communication technology has brought enormous changes to the progress of education. Along with the development of learning methods that are also much developed, whether in terms of the method of personal learning, learning media or learning process. This is due to the price of electronic goods are increasingly expensive. While on the other hand, electronic devices or computer are very necessary in their daily activities.

One example, nowadays, the knowledge of technology, especially computers and its application is the main capital to get a more decent work. In addition, today's the education system has included the curriculum of computer subjects to primary school students, so it is advisable for every educational institution to have a computer set for the learners. So the teacher should develop a learning environment for learners to examine what attracts them and expresses their creativity ideas within consistent constraints and norms. Learning process is essentially a communication process that must be created or realized through the delivery and exchange activities of information between teachers and learners about learning materials. Teachers using an effective and efficient tool is a must to achieve learning objectives.

In addition, teachers are also required to be able to develop and design learning media that will be used for learning needs. Therefore, teachers should have sufficient knowledge and understanding in the preparation of 
instructional media. One of the characteristics of instructional media is that it must contain messages or information to the recipient. Media can process messages and the response of learners so that the media are often called as interactive media. Messages and information brought by the media can be simple messages or complex messages. But the most important is the media are prepared to meet the learning needs and skills of learners and learners can actively participate in the learning process.

The media used has a position as a tool for teachers in teaching. For example, graphics, movies, slides, photos, and learning by using a computer. The point is to capture, process, and rearrange visual and verbal information. As a tool in teaching, media is expected to provide concrete experience, learning motivation, enhancing the absorption and retention of learners. In the foreseeable future, the use of multimedia-based learning in the classroom as a means of teaching and learning is increasingly needed, the media that has been used in the form of a whiteboard with chalk or markers, both lecture and conventional methods should be improved. Nowadays, educators have begun to gain access to use various technologies to improve the effectiveness of the learning and teaching process.

Computers, as one of the technologically valued products, are appropriately used as teaching aids. Various instructional approaches are packaged in the form of computer-assisted teaching programs or CAI (ComputerAssisted Instruction) such as: drill and practice, simulations, tutorials and games can be obtained via computer. The simulation of the virtual reality is created by computers [5], and users can interact with the results revealing the content of the reality of the environment which is called virtual reality. VR is a human-computer interaction format in which a real or imaginary environment is simulated and users can connect and move the world. One alternative effort that can be used that is by utilization technology of Virtual Networking Laboratory (Lavir Networking), hopefully, it will give better result compared to media and method commonly used [6].

Lavir Networking can be used to make network settings flexible by creating segments that match the network department we need. Lavir Networking is one of the leading advanced products in information technology and laboratories. Virtual lab based learning can be used as an alternative to eliminate the limitations of laboratory equipment [5]. Lavir Networking is used to develop an understanding of network layout, network configuration and systematic networking. Lavir Networking itself uses software to configure the network, namely GNS (Graphic Network Simulator) 3 and Oracle Virtual Box. This function is to make the materials and tools of practice a lot more efficient so that the practice of the network can be easily understood by learners.

Further explanation is described in Government Regulation no. 32 of 2013 on National Education Standards for Vocational Secondary School (Vocational Education) in which the purpose is that "Vocational Secondary Education" prioritizes the preparation of learners to enter employment to develop professional attitudes". If referring to Ministerial Decree number 0490 / U / 1990, the purpose of vocational education can be described as follows: a) preparing learners to continue to higher level of education and/or expand basic education; b) improving the ability of learners as members of the community in establishing a good relationship with social, cultural and surrounding environment; c) enhancing the ability of learners to be able to develop themselves in line with the development of science, technology and art; d) preparing learners to enter the work field and develop a professional attitude.

Vocational education has characteristics that are different from other educational units. These differences can be studied from educational goals, substance lessons, educational demands and graduates [7,8]. Vocational education aims to improve intelligence, knowledge, personality, noble character, as well as the skills of learners to live independently and follow further education in accordance with vocational programs. For that to know the process of application of lavir networking model in learning

\section{METHOD}

This type of research is a quantitative research with quasi experiment method (quasi experiment) [9]. Pseudo experimental research in learning is a research to determine whether or not the result of a treatment of learning activities with a particular method, strategy or media approach. In its application, pseudo experiments must follow the procedure and meet the requirements of quasi experiments, especially with regard to controlling variables, control groups, treatment or manipulation of activities and test results [10]. This research is to evaluate the result of applying Lavir Networking model to learners' learning outcomes on Computer and Network Engineering subjects in SMK. The approach used was a quantitative approach and experimental type to be easier in giving special treatment to the experimental group.

Based on its purpose, this research is a part of quasiexperimental research method that is the development of true experimental methods (actual experiments). Experimental research was done by giving certain treatment to research subject concerned. The research used solomon four group design experimental design. The four group design solomon design can overcome the weakness of external validity of pretest-posttest control group designs. If pretest may affect subjects to respond differently compared to the subjects who were not given pretest to treatment, then external validity is disrupted, ultimately unable to make generalizations to the population. This design overcomes these weaknesses. Putting subjects into four groups randomly makes it possible to make the assumption that the pretest scores achieved by groups 3 and 4 would be the same as the pretest scores achieved by groups 1 and 2 .

The experimental group was given treatment of the application of Lavir Networking model and in the control group was given the conventional treatment applied in school. The research design can be seen in Table I.

TABLE I. RESEARCH DESIGN

\begin{tabular}{|c|c|c|c|c|}
\hline Design & Group & Pre-test & Treatment & Post-test \\
\hline \multirow{4}{*}{$\begin{array}{l}\text { Solomon Four } \\
\text { Group }\end{array}$} & 1 & $\mathrm{O}_{1}$ & $\mathrm{X}$ & $\mathrm{O}_{2}$ \\
\cline { 2 - 5 } & 2 & $\mathrm{O}_{3}$ & - & $\mathrm{O}_{4}$ \\
\cline { 2 - 5 } & 3 & & $\mathrm{X}$ & $\mathrm{O}_{5}$ \\
\cline { 2 - 5 } & 4 & & - & $\mathrm{O}_{6}$ \\
\hline
\end{tabular}


Information:

O: average value

$\mathrm{X}$ : treatment

-: not given treatment

The first stage is to conduct a pretest of learners to determine the ability of learners before the treatment. Viewed from the average value of each group, where the average value of $\mathrm{O} 2$ should be greater than $\mathrm{O} 4$ because of the treatment given in group 1 , on the contrary in $\mathrm{O} 5$ without pretest, the average value of $\mathrm{O} 5$ should be better than the $\mathrm{O} 6$ due to the treatment in group 3. In this test, as a prerequisite in the analysis of variance (ANOVA) required, average value of the 4 posttest that have been tested can be seen in Table II.

TABLE II. POSTTEST SCORE ANALYSIS

\begin{tabular}{|l|c|c|}
\hline \multirow{2}{*}{ Pretest } & \multicolumn{2}{|c|}{ Treatment X } \\
\cline { 2 - 3 } & Yes & $\boldsymbol{N p}$ \\
\hline Yes & $\mathrm{O}_{2}$ & $\mathrm{O}_{4}$ \\
\hline No & $\mathrm{O}_{5}$ & $\mathrm{O}_{6}$ \\
\hline
\end{tabular}

The selected 4 Classes; 2 Classes to be experimented and 2 classes as control. Against one experiment class 1 and one control class 1 do the pretest. Against the experimental class 2 given $\mathrm{X}$ treatment. Furthermore, posttest was done to get the final learning result value which then will be able to show the effectiveness of lavir networking and conventional application in improving learners' learning outcomes. This research was conducted at SMK Negeri 1 Bungoro Regency Pangkep. The population in this study was all students Class XI SMK Negeri 1 Bungoro

\section{RESULT AND DISCUSSION}

This research was conducted at SMK Negeri 1 Bungoro. The study was conducted to class XI students consisting of two classes and was divided into 4 groups which were the research samples. The first group is the experimental group using the pretest, in which this group will be given the initial test process before doing the learning process by using lavir netwroking model on Computer Network material. The second group is the control group, in which this group in the learning process did not use the lavir netwroking model (lecture method) on the computer network material but still used the initial test. The third group is an experimental experiment with the learning process using the lavir networking model and without initial test. The fourth group is a control class without using the lavir networking model and without initial test.

This study used The Solomon Four Group Design. In this study the variables studied were the ability of students to install a computer network using lavir networking model with the initial test (X1) and the ability of students to install a computer network without using the lavir networking model with the initial test. (X2). The ability of students to install a computer network by using model lavir Networking without using the initial test (X3). The students' ability to perform computer network installation without using lavir networking model and initial test (X4).

X1 data was taken from the final grade score of the experimental class by using the initial test with 19 samples and X2 data taken from the control class by using the initial test with 19 samples. X3 data was taken from the final grade score of the experimental class without using the initial test with the number of samples of 19 people while the X2 data was taken from the control class by using the initial test with the number of samples of 19 people.

The data were obtained from the scores of learners in the final test after the four groups were given treatment in accordance with the steps specified. The average value, the highest value, the lowest value, the median, the mode, and the standard deviation for each class can be seen in Table III.

TABLE III. PRETEST DATA OF EXPERIMENT Class AND CONTROL CLASS

\begin{tabular}{|l|l|l|l|l|l|l|l|}
\hline \multirow{2}{*}{ Kelas } & \multicolumn{7}{|c|}{ Descriptive Data } \\
\cline { 2 - 8 } & $\begin{array}{c}\text { Mea } \\
\boldsymbol{n}\end{array}$ & $\begin{array}{c}\text { Media } \\
\boldsymbol{n}\end{array}$ & $\begin{array}{c}\text { Varian } \\
\boldsymbol{c e}\end{array}$ & $\begin{array}{c}\text { Std } \\
\text { Deviati } \\
\text { on }\end{array}$ & Min & Max & $\begin{array}{c}\text { Ra } \\
\boldsymbol{n g} \\
\boldsymbol{e}\end{array}$ \\
\hline $\begin{array}{l}\text { Eksperi } \\
\text { men }\end{array}$ & 67.37 & 68 & 32.47 & 5.69 & 59 & 76 & 17 \\
\hline Kontrol & 66.37 & 65 & 29.36 & 5.42 & 54 & 78 & 24 \\
\hline
\end{tabular}

Based on Table III, the pretest results showed the experimental class mean value of 67.37 whereas the control class mean value was 66.37 and the experimental class median value was 68 while the median grade of the control class was 65 . The variance value of the experimental class was 32.47 while the class variance value control was 29.36 and experimental standard deviation value was 5.69 whereas standard deviation value of control class was 5.42. The value of experiment class min was 59 while the control class value was 54 and the max value of the experimental class was 76 while the control class max was 78 and the experimental class was 17 and the control class was 24 . Based on the pretest result of the experimental class and class control did not show a significant comparison of mean values.

TABLE IV. PRETEST DATA OF EXPERIMENT ClASS AND CONTROL CLASS

\begin{tabular}{|c|c|c|c|c|c|c|c|}
\hline \multirow[b]{2}{*}{ Kelas } & \multicolumn{7}{|c|}{ Statistical Data } \\
\hline & Mean & $\begin{array}{c}\text { Me } \\
\text { dia } \\
n\end{array}$ & $\begin{array}{c}\text { Mo } \\
\text { de }\end{array}$ & $\begin{array}{c}\text { Std } \\
\text { Devi } \\
\text { ation }\end{array}$ & Min & $\operatorname{Max}$ & Sum \\
\hline $\begin{array}{l}\text { Experiment } \\
\text { with pretest } \\
\text { (Group 1) }\end{array}$ & 88.32 & 89 & 90 & 5.09 & 78 & 98 & 1678 \\
\hline $\begin{array}{l}\text { Control with } \\
\text { pretest } \\
\text { (Group 2) }\end{array}$ & 79.32 & 78 & 78 & 3.61 & 73 & 89 & 1507 \\
\hline $\begin{array}{l}\text { Experiment } \\
\text { non pretest } \\
\text { (Group 3) }\end{array}$ & 82.68 & 81 & 78 & 4.27 & 78 & 92 & 1571 \\
\hline $\begin{array}{l}\text { Control non } \\
\text { pretest } \\
\text { (Group 4) }\end{array}$ & 76.32 & 78 & 78 & 6.13 & 62 & 84 & 1450 \\
\hline
\end{tabular}

Based on Table IV, the posttest result showed the mean value of experiment with pretest (Group 1) class of 88.32 while the mean value of control with pretest (Group 2) was 79.32. The median value of the experiment with pretest (Group 1) class was 89 while the median grade of control with pretest (Group 2) was 90. The experiment class with pretest (Group 1) classroom value was 90 while the controlclass pretest (Group 2) was 78. The standard deviation value of the experiment with pretest (Group 1) class was 5.09 whereas the standard deviation value of control with pretest 
class was 3.61. Min value of experiment with pretest (Group 1) class was 78 while the control class with pretest (Group 2) was 73. The max experimental grade with pretest (Group 1) was 98 while the max grade of control with pretest (Group 2) was 89 . The sum value of the experiment with pretest (Group 1) class was 1678 while the control class pretest (Group 2) sum value was 1507 . It showed the mean, median, mode, standard deviation, min, max and sum of pretest experiment classes with pretest were higher than control class with pretest. So even with the comparison of posttest experiment results, non pretest was higher than the value of posttest control non pretest. This was influenced by the treatment given to the experimental class, namely the application of lavir networking model in the class.

Based on the research, the result of pretest and posttest from test instrument given in the experimental class and control class are attached in Appendix 3, which then will be obtained the result of the average data of learning result shown in Table V.

TABle V. Average Pretest And Posttest SCORE

\begin{tabular}{|l|c|c|}
\hline \multicolumn{1}{|c|}{ Kelas } & Pretest & Posttest \\
\hline $\begin{array}{l}\text { Eksperimen with } \\
\text { Pretest (Group 1) }\end{array}$ & 67 & 88 \\
\hline $\begin{array}{l}\text { Kontrol with Pretest } \\
\text { (Group 2) }\end{array}$ & 66 & 79 \\
\hline $\begin{array}{l}\text { Eksperimen non } \\
\text { Pretest (Group 3) }\end{array}$ & 0 & 83 \\
\hline $\begin{array}{l}\text { Kontrol non Pretest } \\
\text { Group 4) }\end{array}$ & 0 & 76 \\
\hline
\end{tabular}

Based on Table $\mathrm{V}$, the mean of posttest grade of the experimental class was higher than the average posttest score of the control class. This was influenced by the treatment given to the experimental class, namely the application of lavir networking model in the class.

Network installation lessons in Secondary Schools are intended to provide basic competencies to learners in the utilization of information and communication technologies. The process of learning the installation of the operating system will not be done properly without any computer device. As the main media on learning lavir networking, computer equipment should be maximized in accordance with the needs of the number of students. However, there are still many schools that lack computer so the process of practicum really does not happen. Not to mention the teaching methods used by teachers who tend to be monotonous and rigid so that the learning process of the operating system installation is really passive and boring.

One of the steps that can be done to overcome the above problems is to utilize interactive learning media, namely lavir netwoking interactive learning created using special multimedia software so that detailed work steps can be displayed in real time by computer. Thus, learners can learn directly through lavir networking without always be accompanied by a teacher. This lavir networking model has been implemented in SMK Negeri 1 Bungoro. The effectiveness of the use of lavir networking is known by testing with an experimental experiment. The class was divided into four, the experiment with pretest class (Group 1) treated using lavir networking with the initial test. Control class with pretest (Group 2) that did not use virtual lab. Nonpretest Experiment Class (Group 3) provided virtual lab learned without initial test, while non-pretest control class (Group 4) learned without lavir networking and without initial test.

The implementation of the lavir networking model used a manual guide book that contains tutorials using virtual-based learning media. This guide aims to facilitate learners and educators in the learning process so that learning objectives can be achieved. This manual book consists of oracle, virtual machine, virtual box introduction, virtual box installation, GNS 3 introduction, GNS 3 installation, how to insert router IOS into GNS 3 and how to connect GNS 3 with virtual box. More manual book can be seen in Appendix 14.

Before passing the research, the test instrument to be used was tested first by doing the validity test and reliability test. Validity is a measure that indicates that the variable being measured is indeed the variable that the researcher [11], wanted to study. Meanwhile, according to[12], validity relates to a variable measuring what should be measured. Validity in the study stated the degree of accuracy of the study measuring tool of the actual content being measured. Validity test is a test used to indicate how far the measuring instrument is used in measuring what is measured.

Furthermore, controlling the internal elements for the effectiveness of the use of learning media Lavir Networking Model (in the form of improvement of learning outcomes learners) observed was the result of the treatment of the use of learning media Lavir Networking Model provided as a learning tool. Internal validity is the extent to which the results of a clinical study are unbiased. Some research characteristics affect internal validity. This internal validity is the degree to which the results of the research can be believed to be true or related to the degree of accuracy between the research design and the results achieved. Internal validity is an essential thing that must be met if the researcher wants the results of the study to be meaningful. Internal validity refers to the ability of a research design to exclude or make plausible alternative explanation of results, or make sense of temporary allegations.

In this research, the first thing done in internal validity control was subject selection by choosing group of research subjects from population that have the same relative characteristic. Doing randomization at the time of determining which group will be given facility of learning media using model of lavir networking on eye Computer network basic lessons and conducting pretest prior to the experiment to compare initial ability between the two study subjects.

Furthermore, efforts made to overcome the maturity factor associated with the changes in the experimental results of time travel and natural changes in the form of development (mental) and growth (physical), the period of treatment was not too long (8 meetings only) to get the experimental results.

Furthermore, mortality factor is also one of the internal elements in this study. Efforts made to control mortality factors associated with loss of participants in the study were to validate the study sample (determining the number of samples to be analyzed). For example, in one class consisting of 33 students, to prevent the loss of participants at the time of research, we first determined the samples of the 33 students. However, the study still used the overall learners in the class. 
Furthermore, pretest factors are carried out as a measurement process prior to the conduct of the Research. In order for pretest not to affect the final test result (posttest), the pretest questions are taken back after the pretest has been completed and randomized the item at the time of posttest implementation. Another effort was not to provide the key answer to the pretest and not to discuss the matter.

The other internal elements are instability factors due to inconsistencies in obtaining scores as a result of the measurement process. Efforts done to control were by testing the validity and reliability of research instruments that would be used in the data collection and the last factor of the researcher, related to the expected results of the desired results of the research. The control of the influence of researchers was done by designing experiments that as far as possible not disturbed by the expectations of researchers. Therefore, instructors and observers were used to assist the process of collecting data so that researchers were not actively involved in both groups but only in one group.

Based on the results of the six treatments in this study, it was proved that the application of solomon four group design can minimize the threats of internal and external validity so that the effects caused really occur because the treatment was conditioned by the application of lavir networking model and produced a representative experimental results that can be generalized.

\section{CONCLUSION}

Based on the research results and discussion about the effectiveness of the application of lavir networking model that has been described in the previous chapter, it can be drawn conclusion as follows: The process of application of lavir networking model in learning emphasized the practicum process virtually using computer media aiming for learners to be able to master the lessons optimally. Virtualbased learning can serve as an alternative to eliminate the limitations of laboratory equipment. Lavir networking was used to develop an understanding of network layout, network configuration and systematic network.

\section{ACKNOWLEDGMENT}

Special thank you to the Director General of Higher Education in Indonesia who has provided opportunities in conducting research and community service in 2018.

\section{REFERENCES}

[1] Ted S. Hasselbring.. Use of Computer Technology to Help Students with Special Needs. The Future of Children CHILDREN AND COMPUTER TECHNOLOGY Vol. 10 • No. 2, 2000

[2] Ana Lucia Varbanescu. On Many-Task Big Data Processing: from GPUs to Clouds. University of Amsterdam. The Netherlands, 2013.

[3] Zhigao Zheng. Real-Time Big Data Processing Framework: Challenges and Solutions.Applied Mathematics \& Information Sciences (An International Journal). Appl. Math. Inf. Sci. 9, No. 6, 3169-3190 (2015)

[4] Tianli Li.. Analysis of Computer Network Information Based on "Big Data". EEMS 2017. IOP Conf. Series: Earth and Environmental Science 94 (2017) 012195

[5] Hendra, J. 2012. Pengembangan Laboratorium Virtual untuk Kegiatan Praktikum dan Memfasilitasi Pendidikan Karakter di SMK. Jurnal pendidikan vokasi vol 2, Nomor 1 .

[6] Sofana, I. 2011. Membangun Jaringan Komputer, Membuat jaringan Komputer (Wire \& Wireless) untuk Pengguna Windows dan Linux. Bandung: Informatika.

[7] Djohar, A. 2007. Pendidikan Teknologi dan Kejuruan dalam Ilmu dan Aplikasi Pendidikan. Bandung: Pedagogiana Press. Hal. 12851300 .

[8] Agung, M. 2013. Kajian Pendidikan Teknologi Kejuruan. (Online), (http://www.slideshare.net/agungmilna/kajian-pendidikan-teknologikejuruan-buku-vocation-education-stephen-billet, diakses 7 Maret 2016)

[9] Graziano, A.M \& M.L Raulin. 2011. Research Methods, A Process of Inquiry, 4th ed. Boston: Allyn \& Bacin.

[10] Sugiyono. 2014. Metode Penelitian Kuantitatif Kualitatif dan R\&D. Bandung: Alfabeta.

[11] Cooper dan Schindler. 2006. Business Research Methods. Eighth Edition. New York: McGraw-Hill/Irwin.

[12] Sugiharto dan Sitinjak. 2006. Strategi Menaklukkan Pasar Melalui Riset Ekuitas dan Perilaku Merek. PT. Gramedia Pustaka Utama: 